\title{
DETECTION OF ADENOVIRUS HEXON SEQUENCE IN A CAT BY POLYMERASE CHAIN REACTION (SHORT COMMUNICATION)
}

\author{
B. LAKATOS ${ }^{1 *}$, Judit FARKAS ${ }^{2}$, H. F. EGBERINK ${ }^{3}$, H. VENNEMA $^{3}$, M. C. HORZINEK ${ }^{3}$ and \\ Mária BENKÖ $^{4}$ \\ ${ }^{1}$ University of Veterinary Sciences, H-1400 Budapest, P.O. Box 2, Hungary; ${ }^{2}$ Institute of \\ Microbiology, Semmelweis Medical University, Budapest, Hungary; ${ }^{3}$ Department of \\ Veterinary Virology, Utrecht University, Utrecht, The Netherlands; ${ }^{4}$ Veterinary Medical \\ Research Institute, Hungarian Academy of Sciences, Budapest, Hungary
}

(Received May 23, 1999; accepted June 24, 1999)

\begin{abstract}
Adenoviral nucleic acid was detected by polymerase chain reaction (PCR) in pharyngeal and rectal swab samples of a cat seropositive for adenovirus and suffering from transient hepatic failure. The samples were taken at a one-year interval, and both faecal samples as well as the second pharyngeal sample were positive in PCR performed with general adenovirus primers. The size of the amplified products corresponded to that of the positive control. The identity of the amplicons was also confirmed by DNA sequencing. The $301 \mathrm{bp}$ long hexon gene fragment was very similar to but distinguishable from the corresponding hexon sequence of human adenovirus type 2 . This result suggests the possibility of persistent carrier status and shedding of adenovirus in cats.
\end{abstract}

Key words: PCR, adenovirus, cat

Adenoviruses are medium-sized, nonenveloped, double-stranded DNA viruses that are widespread among vertebrate animals. The main capsid protein called hexon contains highly conserved regions and its gene was described to be the best site of the adenovirus genome for use as a genus-specific hybridisation probe (Scott and Hammond, 1992). The hexon gene region also proved feasible in polymerase chain reaction (PCR) for the detection of adenoviruses in clinical samples.

PCR methods have been described for the diagnosis of human enteral (Allard et al., 1990; Allard et al., 1992; Rousell et al., 1993; Horváth et al., 1996), respiratory (Matsuse et al., 1994; Morris et al., 1996) and ophthalmic (Kinchington et al., 1994; Morris et al., 1995; Saitoh-Inagawa et al., 1996) adenovirus infections. PCR has also been used for grouping adenoviruses (PringÅkerblom and Adrian, 1994; Kidd et al., 1996) and for the detection of different

\footnotetext{
${ }^{*}$ Present address (private): H-1112 Budapest, Vadon u. 7, Hungary;

E-mail: lakbel@net.sote.hu; Fax: (+36 1)3197314
} 
animal adenoviruses (Harasawa et al., 1994; Kiss et al., 1996a,b; PringÅkerblom et al., 1997; Raue and Hess, 1998; Xie et al., 1999). Molecular biological methods are used extensively for the detection and identification of nucleic acids of microorganisms, especially in the case of degraded samples, and hardly or non-cultivable microorganisms (Biksi et al., 1998).

Apart from a case report of a disseminated infection (Kennedy and Mullaney, 1993), and a serosurvey (Lakatos et al., 1996), there were no other data in the literature concerning the occurrence of adenoviruses in cats. Following a preliminary report (Lakatos et al., 1997), in the present communication we describe the molecular biological detection and identification of adenoviral DNA in a cat.

From a two-year-old domestic cat kept as a single pet in isolation, pharyngeal and rectal swab samples were taken twice at a 12-month interval. At the beginning of the examinations, the cat suffered from transient hepatic failure. Subsequently, the animal was repeatedly examined by a group-specific indirect ELISA test (Lakatos et al., 1996) and found highly seropositive for adenovirus hexon antigens throughout 18 months (sampled six times at 1- to 4-month intervals). The pharyngeal and rectal swabs were transported in Dulbecco's Modified Eagle's Medium (Sigma) and stored in Eppendorf tubes at $-70{ }^{\circ} \mathrm{C}$ until processed.

The samples were homogenised with a vortex mixer, then the swabs were removed, and the nucleic acid was extracted with a protocol using silica (Boom et al., 1990). This method had been applied for the extraction of adenovirus nucleic acid (Puig et al., 1994). To avoid contamination during sample preparation, DNA extraction, and PCR, these steps were performed in different separated rooms. The positive control DNA (human adenovirus type 2, HAdV-2) was processed last.

The PCR primers designed for the general detection of human adenoviruses (HAdVs) (Allard et al., 1990) and modified by introducing certain degeneracy (Kiss et al., 1996a) were used. These primers amplify a 301 bp long stretch in the hexon region of almost all mammalian adenoviruses (Kiss et al., 1996a). The primers were synthesised by the Life Sciences B.V. (Breda, The Netherlands) Custom Primer Service.

Amplification was carried out in $100 \mu 1$ volume containing $10 \mu 1$ of $10 \times$ reaction buffer (Perkin-Elmer Cetus), 50 pmol of each primer, $2 \mathrm{U}$ of thermostable Taq DNA polymerase (Perkin-Elmer Cetus), $300 \mu \mathrm{M}$ of each of the four deoxyribonucleoside triphosphates and $10 \mu 1$ of the sample solution containing the target DNA. Sixty $\mu 1$ of mineral oil (Sigma) was added to cover the reaction mixture.

The Step-Cycle program of the DNA Thermal Cycler (Perkin-Elmer Cetus Instruments) was set to denature the DNA at $94{ }^{\circ} \mathrm{C}$ for $30 \mathrm{sec}$, to anneal the primers at $55{ }^{\circ} \mathrm{C}$ for $30 \mathrm{sec}$, and to extend the sequence at $72{ }^{\circ} \mathrm{C}$ for $30 \mathrm{sec}$, for a total of 35 cycles. The denaturation step of the initial cycle was extended to 10 min. HAdV-2 was used as positive control. When no visible product was de- 
tected, a second PCR was performed with the same conditions using $10 \mu \mathrm{l}$ as target DNA from the first completed PCR reaction.

Ten $\mu 1$ of each sample were loaded on a $1 \%$ agarose gel containing $0.5 \mu \mathrm{g} / \mathrm{ml}$ ethidium bromide, and electrophoresed for $1 \mathrm{~h}$ in a horizontal tank in TAE (Tris-Acetate-EDTA) buffer. As molecular mass marker, PstI-digested $\lambda$-phage DNA was loaded on the same gel. The gels were visualised on a UV transilluminator at $302 \mathrm{~nm}$ wavelength and photographed on Polaroid 665 or 667 films.

No positivity with any of the samples was observed in a standard 35-cycle PCR. After re-amplification, however, the first rectal sample and the rectal and pharyngeal samples taken 1 year later gave amplification bands of identical size with the positive control (Fig. 1). The first pharyngeal swab remained negative even after re-amplification, and the positivity of the second pharyngeal sample was weaker than that of the rectal sample. It is possible that the number of virus particles present in the samples was too low, or the conditions of the reaction were not optimal.

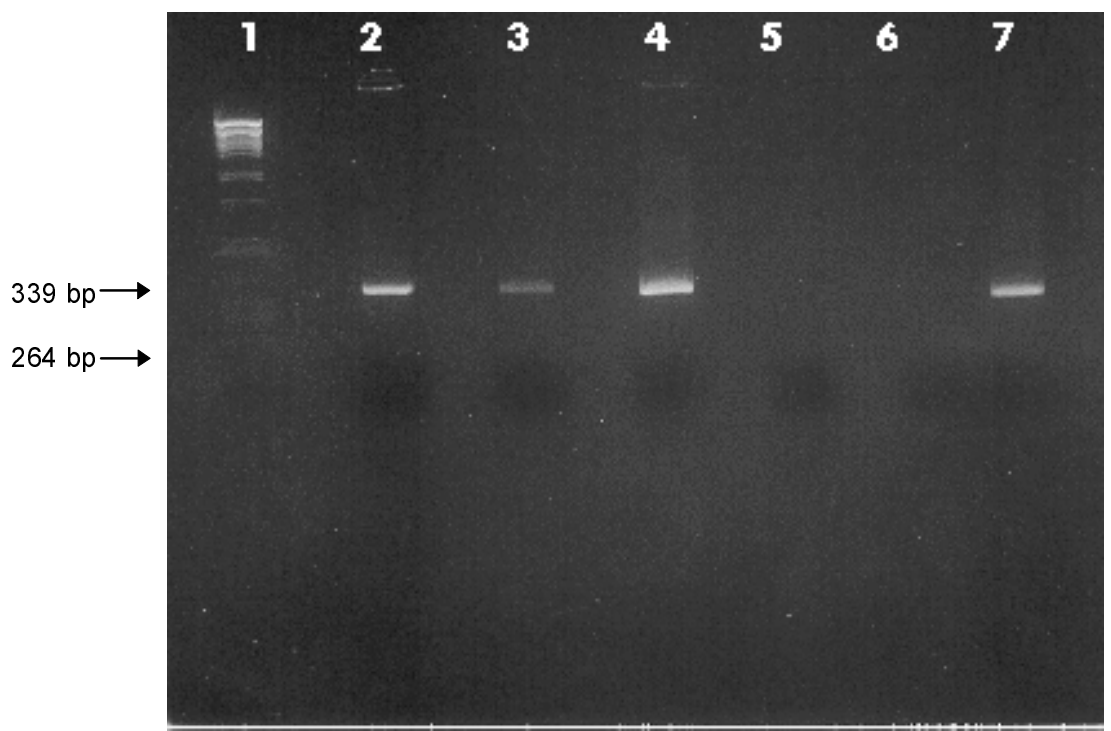

Fig. 1. Gel electrophoresis of the PCR products. Lane 1: molecular mass marker (PstI-digested $\lambda$-phage DNA); lane 2: second rectal sample; lane 3: second pharyngeal sample; lane 4: first rectal sample; lane 5: first pharyngeal sample; lane 6: negative control; lane 7: positive control (HAdV-2 DNA)

The identity of the amplified products has been confirmed by cloning and sequencing. The DNA sequence of the three PCR products (GenBank accession number: AF 172246) was identical, and resembled to but was sufficiently differ- 
ent from the sequence of the corresponding hexon gene region of HAdV-2 to rule out the possibility of contamination (manuscript in preparation). Efforts to isolate the detected adenovirus from the cat are now in progress.

The positive PCR results are suggestive of persistent infection and shedding of adenovirus in the examined animal, although more frequent sampling would have been desirable. The significance or specific clinical effects of adenovirus infection in cats are yet to be clarified. In the presented case, the cat was affected by transient hepatic failure, but the direct correlation between the disease and the adenovirus infection is not confirmed. It is likely, however, that adenovirus infection might influence the outcome of other viral infections, such as feline coronavirus or feline immunodeficiency virus. Our findings might also have an impact on setting the SPF criteria for experimental cats.

\section{Acknowledgements}

A 6-month fellowship for B. L. to Utrecht University was granted by the Tempus Program. A part of this work was supported by the Hungarian Scientific Research Fund (OTKA, grant no. T 030073).

\section{References}

Allard, A., Albinsson, B. and Wadell, G. (1992): Detection of adenoviruses in stools from healthy persons and patients with diarrhea by two-step polymerase chain reaction. J. Med. Virol. 37, 149-157.

Allard, A., Girones, R., Juto, P. and Wadell, G. (1990): Polymerase chain reaction for detection of adenoviruses in stool samples. J. Clin. Microbiol. 28, 2659-2667.

Biksi, I., Kacskovics, I., Mándoki, M., Iván, J., Horváth-Papp, I., Makay, G. and Vetési, F. (1998): Detection of Lawsonia intracellularis in Hungarian swine herds by polymerase chain reaction. Acta Vet. Hung. 46, 415-420.

Boom, R., Sol, C. J. A., Salimans, M. M. M., Jansen, C. L., Wertheim-van Dillen, P. M. E. and van der Noordaa, J. (1990): Rapid and simple method for purification of nucleic acids. J. Clin. Microbiol. 28, 495-503.

Harasawa, R., Tohya, Y., Yoshida, M., Kataoka, Y. and Katae, H. (1994): Two genomic variations in the E1 region of canine adenovirus type 2 strains. Vet. Microbiol. 40, 373-378.

Horváth, M., Szűcs, Gy. and Új, M. (1996): Enteral adenovirus and invagination in infancy (in Hungarian). Orvosi Hetilap 137, 1933-1934.

Kennedy, F. A. and Mullaney, T. P. (1993): Disseminated adenovirus infection in a cat. J. Vet. Diagn. Invest. 5, 273-276.

Kidd, A. H., Jonsson, M., Garwicz, D., Kajon, A. E., Wermenbol, A. G., Verweij, M. W. and De Jong, J. C. (1996): Rapid subgenus identification of human adenovirus isolate by a general PCR. J. Clin. Microbiol. 34, 622-627.

Kinchington, P. R., Turse, S. E., Kowalski, R. P. and Gordon, Y. J. (1994): Use of polymerase chain amplification reaction for the detection of adenoviruses in ocular swab specimens. Invest. Ophthalmol. Vis. Sci. 35, 4126-4134. 
Kiss, I., Matiz, K., Allard, A., Wadell, G. and Benkő, M. (1996a): Detection of homologous DNA sequences in animal adenoviruses by polymerase chain reaction. Acta Vet. Hung. 44, 243-251.

Kiss, I., Matiz, K., Bajmócy, E., Rusvai, M. and Harrach, B. (1996b): Infectious canine hepatitis: detection of canine adenovirus type 1 by polymerase chain reaction. Acta Vet. Hung. 44, $253-258$.

Lakatos, B., Farkas, J., Ádám, É., Jarrett, O., Egberink, H. F., Bendinelli, M., Nász, I. and Ongrádi, J. (1996): Data to the adenovirus infection of cats in Europe (in Hungarian, with English abstract). Magyar Állatorvosok Lapja 51, 543-545.

Lakatos, B., Farkas, J., Egberink, H. F., Vennema, H., Horzinek, M. C., van Vliet, A., Rossen, J., Benkő, M. and Ongrádi, J. (1997): PCR detection of adenovirus in a cat (in Hungarian, with English abstract). Magyar Állatorvosok Lapja 119, 517-519.

Matsuse, T., Matsui, H., Shu, C. Y., Nagase, T., Wakabayashi, T., Mori, S., Inoue, S., Fukuchi, Y. and Orimo, H. (1994): Adenovirus pulmonary infections identified by PCR and in situ hybridisation in bone marrow transplant recipients. J. Clin. Pathol. 47, 973-977.

Morris, D. J., Bailey, A. S., Cooper, R. J., Turner, P. C., Jackson, R., Corbitt, G. and Tullo, A. B. (1995): Polymerase chain reaction for rapid detection of ocular adenovirus infection. J. Med. Virol. 46, 126-132.

Morris, D. J., Cooper, R. J., Barr, T. and Bailey, A. S. (1996): Polymerase chain reaction for rapid diagnosis of respiratory adenovirus infection. J. Infect. 32, 113-117.

Pring-Åkerblom, P. and Adrian, T. (1994): Type- and group-specific polymerase chain reaction for adenovirus detection. Res. Virol. 145, 25-35.

Pring-Åkerblom, P., Blazek, K., Schramlová, J. and Kunstýr, I. (1997): Polymerase chain reaction for detection of guinea pig adenovirus. J. Vet. Diagn. Invest. 9, 232-236.

Puig, M., Jofre, J., Lucena, F., Allard, A., Wadell, G. and Girones, R. (1994): Detection of adenoviruses and enteroviruses in polluted waters by nested PCR amplification. Appl. Environ. Microbiol. 60, 2963-2970.

Raue, R. and Hess, M. (1998): Hexon based PCRs combined with restriction enzyme analysis for rapid detection and differentiation of fowl adenoviruses and egg drop syndrome virus. J. Virol. Meth. 73, 211-217.

Rousell, J., Zajdel, M. E., Howdle, P. D. and Blair, G. E. (1993): Rapid detection of enteric adenoviruses by means of the polymerase chain reaction. J. Infect. 27, 271-275.

Saitoh-Inagawa, W., Oshima, A., Aoki, K., Itoh, N., Isobe, K., Uchio, E., Ohno, S., Nakajima, H., Hata, K. and Ishiko, H. (1996): Rapid diagnosis of adenoviral conjunctivitis by PCR and restriction fragment length polymorphism analysis. J. Clin. Microbiol. 34, 2113-2116.

Scott, T. T. and Hammond, G. W. (1992): Conserved sequences of the adenovirus genome for detection of all human adenovirus types by hybridization. J. Clin. Microbiol. 30, 1703-1710.

Xie, Z., Amin, A. F., Girschik, T. and Kahn, M. I. (1999): Detection of avian adenovirus by polymerase chain reaction. Avian Dis. 43, 98-105. 